\title{
Simple Foot Elevator (SFE) Tools to Promote Comfort for Diabetic Patient during Wound Care
}

\author{
Nuh Huda* and Dini Mei Widayanti \\ Hang Tuah Surabaya Health Institute Surabaya, Indonesia \\ Jalan Gadung, No. 1, Surabaya, Jagir, Wonokromo, Kota Surabaya, Jawa Timur 60244 \\ *Corresponding author: badawiff@ gmail.com
}

\begin{abstract}
Background: Increasing the number of patients with DM, complications are also increasing, one of them is ulceration of the lower leg, with or without infection and cause damage to the underlying tissue, hereinafter referred to as diabetic foot (KD) or diabetic foot wound. In the world, the number of diabetic foot patients is expected to continue to rise. Objective: This study is to analyze the comfort of patients and nurses when performed wound care with a simple foot elevator (SFE) tool. This type of research is quasi experimental Pre and Post Test Without Control Design by creating a prototype called SFE. It was then tested on 30 DM patients with diabetic ulcer complications in the lower extremity and 12 nurses. The variables of this study were to measure the comfort of patients and nurses when using SFE through a questionnaire. Data processing research with Mann Withney test with significance level $(\alpha=$ 0,05) or CI $=95 \%$. Results : Mann Whitney Test Result research on the use of SFE in diabetic foot wound patients that nurse comfort value in performing diabetic ulcer treatment $p=0.001$, patient comfort $p=0.001(p<\alpha=0.005)$. Conclusion: The use of SFE aids in the treatment of diabetic foot wounds can provided the comfort of nurses and patients. So it can be recommended as one alternative tool that can be used in wound care
\end{abstract}

Key word: Diabetic foot wounds, Simple Foot Elevator, Comfort

\section{INTRODUCTION}

Diabetes Mellitus (DM) is a clinical syndrome of metabolic abnormalities, characterized by hyperglycemic caused by insulin secretion defects, insulin working defects or both. DM is often accompanied by various short-term and long-term complications, this complication causes increased morbidity, mortality, and decreased quality of life (ADA, 1999). In the world, the number of DM patients is estimated at 171 million people and this condition is predicted to increase to 366 million in 2025 (Synder RJ, et al, 2010).

Increasing the number of people with diabetes mellitus, complications are also increasing, one of them is ulceration of the lower leg, with or without infection and cause damage to the underlying tissue, hereinafter referred to as diabetic foot (KD) or diabetic foot wound (Apelqvist J, bakker K, Hotum W, Schaper N, 2008). Manifestations may include dermopathy, cellulitis, ulcers, gangrene, and osteomyelitis. KD is a complex problem and is the main reason why DM patients are treated in hospitals that during the treatment cost is very expensive and often not affordable by most of the general public (Frykberg R, et al, 2008).

Approximately $15 \%$ of patients with DM will experience ulcers in the legs. The diabetic incidence of various populations ranges from 2-10\%. Neuropathy, overactive 
deformity of the foot, low blood glucose control, long-standing DM are factors causing diabetic ulcers (Frykberg et al., 2008). Ulcer handling can be done on an outpatient basis, but if infection is to be the main reason to undergo hospitalization because the treatment will be more controlled than outpatient treatment.

According to the National Institute of Diabetes and Digestive and Kidney Disease, an estimated 16 million Americans are known to have diabetes, and millions of them are at risk for diabetes. Of all diabetics, $15 \%$ suffer from ulcers in the legs, and $12-14 \%$ of those suffering from leg ulcers require amputation. Incidence of diabetic ulcers 2-3\% and prevalence 4-10\%, men more often than women. Age distribution is rarely seen in 40-49 years of age and the most at age over 60 years.

Based on preliminary study results and interviews with nurses working in the diabetic ulcer care unit Navy Hospital Surabaya, for the treatment of diabetic ulcers, takes between 25 and 60 minutes for each patient, even for new cases where diabetic ulcer patients with new infections are first examined, diabetic ulcer treatment takes between 60 minutes and 100 minutes. The tool used as a foot rest in the treatment of diabetic ulcers using an inverted basin, pillow, small chair or other. The duration of diabetic foot ulcer treatment is due to the characteristics of the ulcer. The larger and heavier the ulcer level, the longer the treatment process of the wound. In addition, when performing treatment for diabetic ulcers, the nurse has difficulty cleaning the wound on the lower side of the foot, requiring longer time to reach the lower ulcers area or hard to reach areas. The impact of length of treatment of diabetic ulcer wounds is the emergence of fatigue and discomfort of patients and nurses, as well as longer or less efficient treatment time.

Treatment of diabetic ulcers performed by nurses in several hospitals such as legs who suffered leg injuries attempted to hang over the side of the bed; or attached to the bed with a lazy coat; or placed on top of a bent, propped up with a plastic basin and so on. Conditions such as these cause various problems such as the risk of nurse's back pain, soiling the bed; difficulty while performing treatment so it takes longer; cause pain of the patient because of pressing metal (bent), and cause fatigue both patient and nurse who do diabetic ulcer treatment.

Based on this background, researchers are interested in making a tool to help ease the treatment of diabetic ulcers called "SFE" (Simple Foot Elevator), which is a tool to facilitate the treatment of diabetic ulcers by lifting the legs that have ulcers and maintain it until the end of treatment without causing pain or fatigue either patient or nurse. This tool serves to facilitate the treatment of diabetic ulcer wounds also provide comfort in patients when the treatment of diabetic ulcers and reduce swelling of the feet. Research Objectives is using that SFE (Simple Foot Elevator)) can help to treat diabetic ulcers more comfortably

\section{METHOD}

The population of this study were DM patients with diabetic ulcer complications. Sampling technique with Consecutive Sampling. Research sample) 30 respondents (Patient) and 12 Respondents (nurses), with Consecutive Sampling, with inclusion criteria was DM patient with diabetic ulcer complication in lower extremity area performed diabetic ulcer treatment either in Polyclinic or space hospital care; and willing to be a respondent.

Data collection was conducted through questionnaires to assess the effective and efficient diabetic ulcer treatment was the implementation of diabetic ulcer treatment in accordance with the Standard Operating Procedures (SPO) that was set up can be easier and faster without accompanying fatigue complaints from both the patient and the nurse due to the length of treatment. 
Measured variable was comfort that was perception of nurse comfort when doing diabetic ulcer treatment. Scale: ordinal (uncomfortable, comfortable and comfortable), as well as perceptions of nurses and patient comfort. Processing and data analysis used descriptive univariate analysis, and bivariate with Mann-Whitney test, with significance level $(\alpha=0,05)$ or $\mathrm{CI}=95 \%$.

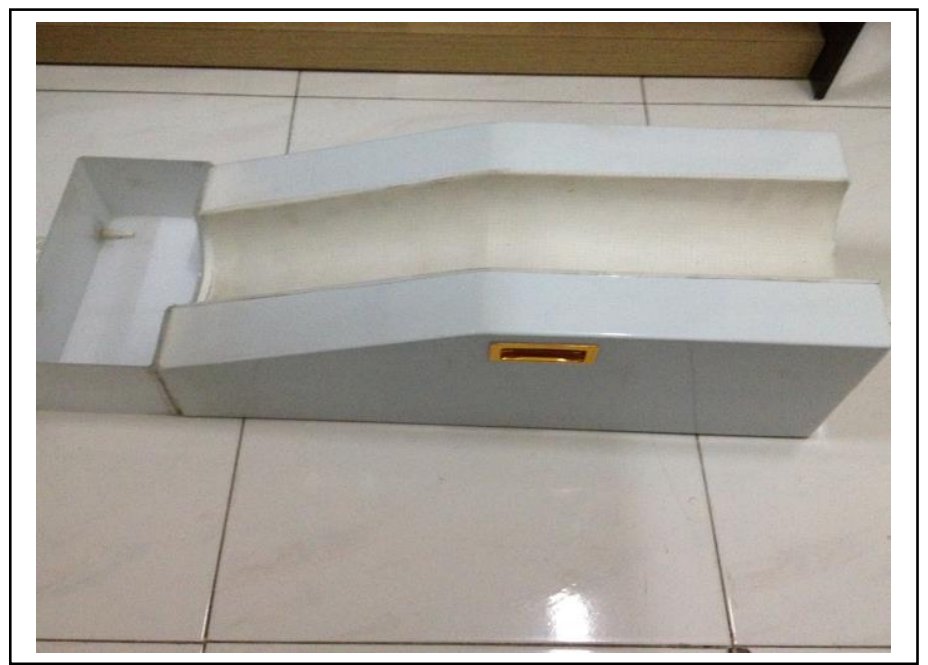

Figure 1 Tool of Simple Foot Elevator for diabetic foot ulcer

RESULT AND DISCUSSION

\section{Characteristic of Respondent's}

Table 1 General Data of Respondents

\begin{tabular}{|c|c|c|c|c|c|c|}
\hline \multirow[t]{2}{*}{ No } & \multirow{2}{*}{\multicolumn{2}{|c|}{ Characteristic }} & \multicolumn{2}{|c|}{ Patient } & \multicolumn{2}{|c|}{ Nurses } \\
\hline & & & Total & $\%$ & Total & $\%$ \\
\hline \multirow[t]{2}{*}{1} & Sex & Man & 7 & $23,3 \%$ & 2 & $16,7 \%$ \\
\hline & & Woman & 23 & $76,7 \%$ & 10 & $83,3 \%$ \\
\hline \multirow[t]{3}{*}{2} & age & $30-40$ year & 3 & $10 \%$ & 4 & $33,3 \%$ \\
\hline & & $41-50$ year & 9 & $30 \%$ & 8 & $66,7 \%$ \\
\hline & & $>50$ years & 18 & $60 \%$ & - & - \\
\hline \multirow[t]{4}{*}{3} & education & Basic & 1 & $3,3 \%$ & - & \\
\hline & & High school & 4 & $13,3 \%$ & - & \\
\hline & & Senior high school & 24 & $80.3 \%$ & - & \\
\hline & & University & 1 & $3,3 \%$ & 12 & $100 \%$ \\
\hline \multirow[t]{2}{*}{4} & Married status & Married & 26 & $87,1 \%$ & 12 & $100 \%$ \\
\hline & & Widower/widow & 4 & $12,9 \%$ & & \\
\hline \multirow[t]{2}{*}{5} & wounds degree & $1-2$ & 25 & $83,3 \%$ & & \\
\hline & & $3-4$ & 5 & 16,7 & & \\
\hline \multirow[t]{2}{*}{6} & Inflammation & Ada & 3 & $10 \%$ & & \\
\hline & wounds & Tidak ada & 27 & $90 \%$ & & \\
\hline \multirow[t]{2}{*}{7} & Nekrotic & YES & 2 & $6,7 \%$ & & \\
\hline & & No & 28 & $93,3 \%$ & & \\
\hline \multirow[t]{2}{*}{8} & Pain & Yes & 22 & $73,3 \%$ & & \\
\hline & & NO & 8 & $26,7 \%$ & & \\
\hline \multirow[t]{2}{*}{9} & Works & Works & 20 & $66,7 \%$ & & \\
\hline & & No & 10 & $33,3 \%$ & & \\
\hline \multirow[t]{3}{*}{10} & Length of works & $<1$ years & 2 & $6,6 \%$ & 2 & $16,7 \%$ \\
\hline & & $1-5$ year & 20 & $66,7 \%$ & 4 & $33,3 \%$ \\
\hline & & $>5$ year & 8 & 26,7 & 6 & $50 \%$ \\
\hline
\end{tabular}




\section{Characteristics of Respondents based on Comfort Level}

Table 2 Characteristics of Respondents (nurses) based on Comfort Level Before and After Given Simple Foot Elevator On Nurses In Performing Treatment of Diabetes Injuries

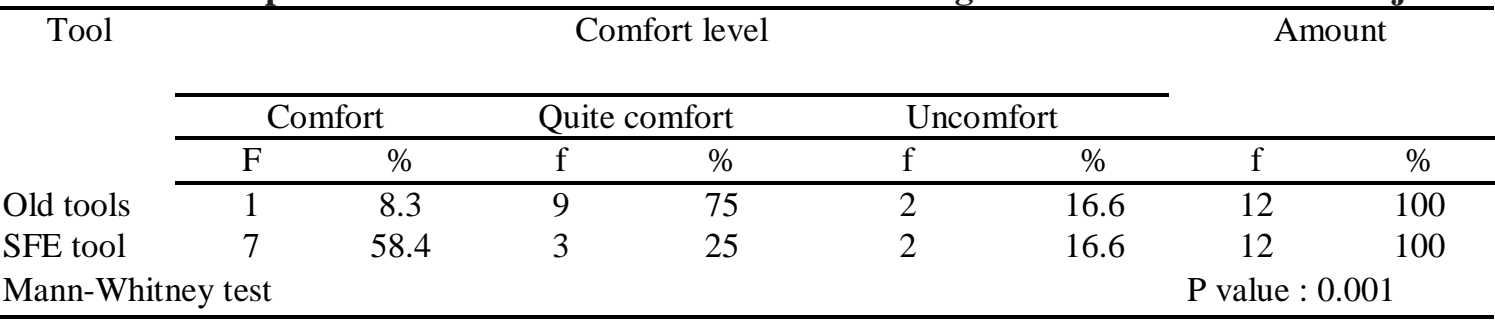

Table 2 showed that from 12 respondents, the average score of comfort performed wound care using the Simple Foot Elevator were 7 respondents $(58.3 \%)$ said comfortable, 3 respondents (25\%) quite comfortable, and 2 respondents $(16.6 \%)$ uncomfortable. While the comfort level using the old tool is 1 respondent (8.3\%) said comfortable, 9 respondents $(75 \%)$ quite comfortable, and 2 respondents $(16.6 \%)$ uncomfortable. The result of statistical test by using Mann-Whitney test was 0.001 , the result $\mathrm{p}$ was less than $\alpha$, and it was meaning that statistically showed that the use of SFE (Simple Foot Elevator) tool is convenient to be used by nurses when performing diabetic foot ulcer treatment in Room 3 Navy Hospital Dr. Ramelan Surabaya. $(\mathrm{p}=0.001)$.

Table 3 Respondent Characteristics (Patient) Based on Patient Comfort Level when wound care is done using old tools and SFE tools

\begin{tabular}{|c|c|c|c|c|c|c|c|c|}
\hline & \multicolumn{6}{|c|}{ Comfort levels } & \multirow{2}{*}{\multicolumn{2}{|c|}{ Amount }} \\
\hline & \multicolumn{2}{|c|}{ comfort } & \multicolumn{2}{|c|}{ Quite comfort } & \multicolumn{2}{|c|}{ Un comfort } & & \\
\hline & $\mathrm{f}$ & $\%$ & $\mathrm{~F}$ & $\%$ & $\mathrm{~F}$ & $\%$ & $\mathrm{~F}$ & $\%$ \\
\hline Old tool & 0 & 0 & 15 & 50 & 15 & 50 & 30 & 100 \\
\hline SFE tool & 9 & 30 & 18 & 60 & 3 & 10 & 30 & 100 \\
\hline \multicolumn{5}{|c|}{ Mann-Whitney test } & \multicolumn{4}{|c|}{$P$ value $; 0.001$} \\
\hline
\end{tabular}

Based on Table 3 shows the amount or value of comfort obtained from the assessment of each respondent questionnaire. Obtained amount of comfort value when performed diabetic foot ulcers using the old tool in the category of uncomfortable as much as 15 respondents (50\%), the category quite comfortable as many as 15 respondents $(50 \%)$, no statement saying comfortable with old tools. While respondents were given a new SFE tool, it was found that 9 respondents (30\%) stated comfortable, 18 respondents $(60 \%)$ said quite comfortable and 3 respondents (10\%) stated uncomfortable. Result of statistic test with Mann-Whitney test got result $p=0.001$. Which it was mean there was a significant difference between the old tool and the new tool.

The elevation is done so that the peripheral circulation does not accumulate in the distal areas of the ulcer so that the circulation can be maintained (Frykberg, 2002; Simon, et.al, 2004 in Wulandari, 2015). However, because of the effects of gravity causes blood flow will tend toward the periphery, especially the feet that have ulcers. Elevation of the lower extremities is done to overcome the effect (Frykberg, 2002 in Wulandari, 2015). Based on the results of observations made, the old tool form used to treat the wound is only able to support part of the foot or only at a certain place. So that nurses who do wound care should use the same tool or other tools such as bent or basin is reversed and bottle NS to be able to support the legs of patients. In terms of size, old tools also have small size. Therefore, when performing wound care, especially on the bottom of the foot, the nurse must reposition the patient's legs. That was by encouraging the patient to sleep on his stomach so that the bottom of the patient's foot can be reached. 
Comfort can be influenced by several factors: circulation, natural or climatic forces, noise, smell or smell, shape, safety, cleanliness, beauty, lighting (Judge, 2006). One of the factors that affect comfort is the shape, the shape of the construction plan must be adjusted to the size of human standards in order to create a sense of comfort (Hakim, 2006). SFE tools also have shelters of dirt, water and scraps that are not used can be accommodated in containers that have been provided, so the nurse no longer need to use some tools such as plastic or other containers. Judging from the efficiency of time, with this tool also the maintenance time is done faster, thus reducing the fatigue element felt by the nurse at the time of foot wound care.

SFE (Simple Foot Elevator) can minimized the occurrence of discomfort to the nurse when performing wound care. As no need to trouble to dispose of water when did watering on the feet of patients because there has been a water reservoir, the material of the tool used to support the feet strongly so that nurses who do wound care not to worry if the foot will fall. SFE (Simple Foot Elevator) is one tool that serves as a foot support when doing diabetic foot ulcers. This tool is used to help facilitate nurses in the treatment of diabetic ulcers. SFE as a tool instrument used for tool extremity elevation has taken account of client's security and convenience. The risk of injury is prevented by the design of a strong and sturdy tool that can support the legs of both the lower legs, knees and thighs. This tool is also equipped with a water container that can hold water when nurses do wound care.

The wound or grade of the wound resulted in the length of treatment so that the feet hung longer while using the old tools and because the wound was hard to reach so that the support should be added in order to reach parts of the wound as in the heel or calf, gangrene has occurred in all legs and lower legs distal Y, 2016). The condition can be affected by the pain that arises or tingling. The shape of the old tool or the cushion is less precise because the point of support existing on the old tool or commonly used pillow is only concentrated at one point so that if the wound treatment takes a long time can cause tingling because blood vessels failed dilated as a response to increased blood flow requirements, then network ischemia will occur.

Another Study on the Effect of ERLESS or Foot Buffer on Patient Comfort On Diabetic Foot Ulcers (Sukmana M, 2016) treats patients with diabetic foot ulcers by positioning feet $30^{\circ}-45^{\circ}$ to reduce pain and reduce edema so as to enhance comfort patient. This research got the result that with height $30^{\circ}$ got 10 people $(71,4 \%)$ patient feel comfortable, and 8 people $(57,1 \%)$ patient uncomfortable. Using a $45^{\circ}$ angle as many as 12 people $(85.7 \%)$ comfortable patients and 11 people $(78.6 \%)$ uncomfortable patients. Previous research on the Effects of ERLESS or Foot Buffer on Patient Comfort on Diabetic Foot Ulcers (Sukmana M, 2016) explains that improving the recovery of physiological function, creating hemodynamic balance is the principle of action in Kolcaba theory.

\section{CONCLUSION}

Based on observations made at the research site and based on the theory and research associated with this research obtained the result that the tool SFE (Simple Foot Elevator) can provide comfort effects patients. Wound healing is a complex and dynamic process because it is a bio cellular and biochemical activity that occurs in a continuous manner, thus requiring a means that can foster a sense of comfort in patients who are treated. The treatment of diabetic foot wounds requires patience and persistence in their care, requiring time, patience, comfort and of course an easy tool to use when performing treatment, especially in areas that are difficult to reach. The results of this study can be concluded that the tool SFE (Simple Foot Elevator) is able to provide comfort nurses and patients. So it can be recommended as one alternative tool that can be used in wound care. 


\section{REFERENCE}

Adyagreenis. (2010). Masalah Diabetes di Indonesia. Dalam : Noer, dkk, editors, Ilmu Penyakit Dalam, Jilid I, Edisi ketiga, Penerbit FK UI, Jakarta.

American Diabetes Association (ADA), (2009). Standards of Medical care in Diabetes. EGC. Jakarta

Black \& Hawks, (2014). Keperawatan Medikal Bedah: Manajemen Klinis untuk Hasil yang Diharapkan Edisi 8. Singapore: Elsevier.

Brunner \& Suddart. (2010). Buku ajar Keperawatan Medical Bedah, Berdasarkan Analisis klinis. EGC, Jakarta.

Bryant. RA. \& Nix. DP. (2007). Acute \& Crhonic Wounds. Current Management Consepts. USA. St. Missouri. Mosby Elsevier

Dushay, J dan Abrahamson, M.J., (2010). Insulin therapy for type 2 diabetes: Making it work. The Journal of Family Practice. Vol. 59, No. 04: E1-E8.

Fryberg. R.G. et al. (2008). Diabetic Foot Disorder; A Clinical Practice Guidline. USA. Data Trace Publishing

Gitarja, WS (2008). Perawatan Luka Diabetes. Edisi ke 2. Indonesia: Wocare.

Handaya, B. (2010). Perawatan Luka Diabetes; Berdasarkan Konsep Manajemen Luka Modern dan Penelitian Terkini. Yogyakarta: Graha Ilmu.

Hakim, S. (2006). Penatalaksanaan Pasien Diabetes Mellitus, Penerbit FK UI, Jakarta.

Huda, N. (2010). Pengaruh Hiperbarik Oksigen (HBO) Terhadap Perfusi Perifer Luka Gangren Pada Penderita DM Di RSAL Dr. Ramelan Surabaya http://lib.ui.ac.id/file?file=digital/20283057-T\%20Nuh\%20Huda.pdf diunduh pada 16 Desember 2016.

Kozier, B. (2011). Nursing Understanding Disease. New York: Lippincott William \& Wilkins.

La Mone \& Burke, (2008). Medical Surgical Nursing: Critical thinking in Client Care. Elsevier. Singapore

Notoatmodjo, S. (2012). Metodologi Penelitian Kesehatan. Jakarta: Rineka Cipta.

Maryunani, Anik. 2015. Perawatan Luka (Modern Woundcare) Terlengkap dan Terkini. Bogor: In Media.

Pranoto, A., (2008). Achieving Ambitious Glycaemic Target in Diabetes. Surabaya, Erlangga.

Sukmana, M. (2016). Penggunaan Erless $30^{\circ}$ dan $45^{\circ}$ Terhadap Circumference Edema, Kenyamanan Dan Fungsi Pada Ulkus Kaki Diabetes Di Rumah Sakit Samarinda http://repository.umy.ac.id/bitstream/handle/123456789/7534/12.Naskah\%20Publika si.pdf diunduh tanggal 16 Januari 2017.

Satwiko. (2009). Panduan Praktis Pemilihan Balutan Luka Kronik. Jakarta: Mitra Wacana Medika.

Scheafer, A. (2010). Foot Care in Patients with Diabetes. Nursing Stand. 19;17 (23): 6162,64,66,68 from : http://gateway.ut.ovid.com.

Synder, RJ et al. (2010). Management of Diabetic Foot Ulcers https://www.ncbi.nlm.nih.gov/ diunduh tanggal 11 Januari 2017

Starkey, D.,G., (2004). Diabetic foot ulcers : prevention, diagnosis and classification. American Family Physician.

Tomey, A.M. \& Alligod, M.R. (2006). Nursing Theories and Their Works. Sixt Ed. St.Louis; Mosby Elsevier

Wulandari, Indah. Yetti, Krisna. Hayati, Tutik Sri. (2015). Pengaruh Elevasi Ekstremitas Bawah Terhadap Proses Penyembuhan Ulkus Diabetik Di Wilayah Banten 
http://repository.unri.ac.id/xmlui/handle/123456789/7472 diunduh tanggal 10 Februari 2017.

Zaidah. S. (2005) Petunjuk Praktis. Terapi Insulin Pada Pasien Diabetes Melitus. Pusat Penerbitan Ilmu Penyakit Dalam. Jakarta. Hal. 9-12. FKUI. 